\title{
The Impact of School Culture and Organizational Commitment to Performance Teachers in the SD Negeri Keluang District
}

\author{
Siti Munajah ${ }^{1 *}$, Yasir Arafat ${ }^{2}$, Mulyadi $^{2}$ \\ ${ }^{1}$ SDN Keluang, South of Sumatera, Indonesia \\ ${ }^{2}$ Universitas PGRI, Palembang, Indonesia \\ *Corresponding author. Email: sitimunajah970@gmail.com
}

\begin{abstract}
The goal of this study was to evaluate the influence of school culture and organizational commitment on the performance of public elementary school teachers in the Keluang District of Musi Banyuasin Regency. This research was carried out on teachers in the Keluang Subdistrict, Musi Banyuasin Regency. The sample size was taken by as many as 70 teachers. The sampling technique was intended for sampling, namely where the respondents were some of the teachers in the Keluang Subdistrict, Musi Banyuasin Regency. Data collection was carried out by distributing questionnaires using the Likert 5-point scale to measure 67 items of the statement. The method of analysis used is a multi-linear regression analysis. The findings have shown that at the same time, organizational commitment and school culture had a significant impact on teacher performance. Second, this organizational dedication had a partial and important effect on the output of teachers. Third, school culture has had a partial and important effect on the success of teachers.
\end{abstract}

Keywords: School Culture, Organizational Commitment, Teacher Performance

\section{INTRODUCTION}

Quality is an issue that concerns everyone from different fields of work and services around the world, including education. For the people of Indonesia, expectations of quality are so high today, because the quality of education issue still does not meet the expectations of all parties.

Improving the quality of education is influenced by interlinked work habits, work culture and organizational culture. Without a culture of work and an organizational culture that leads to a culture of quality work, efforts to improve quality optimally will not be achieved as expected.

There are a variety of factors that affect the success of public organizations. A number of factors include organizational commitment, organizational culture and job satisfaction. This is because some of these factors can improve the performance of employees in achieving the objectives of the organization. It therefore takes an organizational commitment to make this happen. This commitment can be fulfilled if individuals within the organization exercise their rights and obligations in accordance with their respective duties and functions within the organization, because the achievement of the organizational objectives is the work of all members of the organization who are collective [1].

Commitment is a situation in which the individual parties to the organization and its objectives and desire to remain members of the organization. On the basis of this definition, organizational commitment includes elements of organization loyalty, involvement in work, and acceptance of the organization's values and objectives. Where loyalty, involvement and acceptance are linked to organizational performance. The commitment of the teacher is the strength to run school programs. The teacher's high commitment to school will make it easier to achieve school goals [2].

Organizational culture is another factor that is no less important to influence organizational performance than organizational commitment. In an organization, of course, there are many factors that influence a person to achieve his or her goals, while the course of an organization is influenced by the behavior of many individuals who have their respective interests. Organizational culture is therefore very important, because it is the habits that exist in the organization. 
These habits govern the behavioral norms that must be followed by the members of the organization in order to produce a productive culture. A productive culture is a culture that can make the organization strong and achieve the objectives of the organization.

Organizational culture is a collection of unique characteristics that organizations retain, referring to a system of common meanings carried by members that distinguishes an organization from other organizations [2]. The quality of the school will also be affected by school culture. Different school cultures have a different impact on the quality of each school. In this regard, Schein [3] claims that the culture of work is a culture within an organization that contributes to a common meaning framework shared by participants that separates the organization from other organizations.

Cultural history can also be seen as a behavior, values, attitudes and way of life to make adjustments, and at the same time as a way of seeing and solving problems [4]. Work culture is thus, in reality, the prevailing principles disseminated within the organization and used as the working ideology of the personnel of the organisation [5]. Organizational culture as a value, a shared assumption of the members of the organization. Organizational culture is the assumption, belief, values and shared perceptions of organizational members that form and give an impression of attitudes, behaviors and instructions to solve problems [6]. In other words, cooperation exists between members who have vision and mission elements, resources, a clear legal basis for the structure and anatomy in order to achieve certain objectives [7]. This organizational culture includes regular behavior, norms, values, philosophy and rules such as principles/guidelines for members to work in an organization [8].

Working community, job discipline and work environment together have a positive impact on the success of teachers [9]. School culture and commitment affect teacher performance; commitment is an intermediary in the relationship between school culture and teacher performance; and engagement with teacher performance [10].

The impact of organizational culture on the performance of lecturers, the effect of commitment on the performance of lecturers and the impact of organizational culture and succession planning on the performance of lecturers at PTS Jakarta [11]. There is an important positive impact on the success of Gun State Vocational High School teachers in the school culture. There is an important positive impact on the success of Gunungkidul Regency State Vocational High School teachers in the school culture [12]. Organizational engagement affects the performance of teachers, the organizational culture has an effect on the performance of teachers [13]. The term employee satisfaction (job satisfaction) is described as a good vibe for one's job as a result of a job evaluation [2]. Teacher job satisfaction creates a sense of pleasure in carrying out teaching and learning activities and other additional tasks.

The definition of work satisfaction according to Robbins and Judge is that a positive feeling about a person's job is the product of a characteristic evaluation (work satisfaction as a pleasant impression about one's work as a result of evaluating one's qualities). In the meantime, a number of experts theoretically explain the model of job satisfaction. Need fulfillment, according to Mc Clelland in Robbins with regard to job satisfaction, states that in an individual there are three life needs that drive their behaviour, namely: (a) the need for achievement, (b) the need to relate to other people (the need for affiliation), (c) the need for power (need for power). The view of Kreitner and Kinicki in Robbins regarding job satisfaction is that there is a difference, the fulfilled expectations represent the difference between what an individual expects from a job and what he actually receives.

Still, in the view of Kreitner and Kinicki, it is stated that the underlying value is satisfaction that arises from the perception that a job makes it possible to fulfill the important values of an individual's work. Teachers can therefore increase satisfaction by structuring the work environment, rewarding and recognizing values associated with it. Generally, job satisfaction depends on the degree to which the output values obtained between individuals in their work correspond to their perception of the capacity of these results. Fairness is also a factor affecting job satisfaction.

This research was conducted in the SD Negeri district of Keluang, Musi Banyuasin Regency. From the results of the initial observations made by researchers in several elementary schools in the Keluang District on 3 March to 7 March 2020. Researchers have identified several phenomena of teacher performance that are still in the low category. The performance of the teacher is still low, which can be seen from a learning process that is not optimal.

Researchers have also identified problems in the employment of teachers that are still not good, including (1) teachers who are not loyal to their profession, as indicated by the presence of teachers who have other jobs and give priority to other jobs compared to their profession as teachers; (2) there are still teachers who do not participate in school activities; (3) low work responsibility, as indicated by the fact that there are still teachers who leave the classroom before the class ends and postpone assignments; (4) Teachers have not fully provided the best service to students, as indicated by the fact that there are still teachers who have not prepared a lesson plan and rarely make learning innovations; (5) not yet proud of the teaching profession, as shown by the fact that there are still teachers who do not really 
teach and do not maintain correct behavior in front of the students.

The commitment of the teacher organization plays an important role in improving the standard of school education if the commitment of the teacher organization is still not strong, it can hinder the development of quality human resources.

In addition, the conditions encountered by researchers related to school culture have shown that the school is still unable to build a favorable school culture, namely a school culture that can build a teaching discipline, a teacher achievement spirit, and a teacher performance, particularly in the learning process.

\section{METHODS}

This form of analysis is quantitative, that is, according to Musfiqon [29], which focuses on the analysis of empirical hypotheses to also be quantitatively observed. Quantitative analysis is a method that uses data in the form of numbers as a way to interpret knowledge about what you want to know. The analysis uses a lot of numbers, starting with data collection, data interpretation and the display of research results. The study consisted of two independent variables, namely School Culture $\left(\mathrm{X}_{1}\right)$, Organizational Commitment $\left(\mathrm{X}_{2}\right)$, while the dependent variable was teacher work performance (Y). Quantitative data collection analysis has been performed.

This experimental approach uses partial and parallel regression models used for study or theories where the researcher wants to know the effect or relation of a variable to a dependent variable where one of the independent variables is monitored. (made permanent) according to Sugiyono [30], the ex post facto research design is a research that aims to investigate events that have occurred. The population of this study was all educators in the SD Negeri in Keluang District, which consisted of 295 teachers. This sample was obtained by researchers using sampling methods, namely sampling techniques which provide equal treatment for each portion (member) of a sample to be identified as survey participants [30].

Data collection techniques in this study were carried out using questionnaires, interviews, observations or observations, examinations or tests, documentation and so on. Data collected by using the Likert scale model. The analytics methodology included simple regression and linear regression with SPSS For Windows version 25.0.

\section{RESULTS AND DISCUSSION}

\section{1) The Effect of School Culture on Teacher Work performance}

The design of the impact of school culture and teacher output is expressed in the form of the $\mathrm{Y}$ regression equation $\mathrm{Y}=24.247+0.746 \mathrm{X}_{1}$. The Linear Regression Significance Level can be seen in the table below.

\begin{tabular}{|c|c|c|c|c|c|}
\hline & $\begin{array}{l}\text { able } 1 . \mathrm{Si} \\
\text { culture o }\end{array}$ & $\begin{array}{l}\text { nifican } \\
\text { teache }\end{array}$ & $\begin{array}{l}\text { e of the influen } \\
\text { work perforn }\end{array}$ & $\begin{array}{l}\text { ce of } \mathrm{sc} \\
\text { ance }\end{array}$ & \\
\hline \multirow[t]{2}{*}{ Model } & \multicolumn{2}{|c|}{$\begin{array}{l}\text { Unstandardized } \\
\text { Coefficients }\end{array}$} & \multirow{2}{*}{$\begin{array}{l}\text { Standardized } \\
\text { Coefficients }\end{array}$} & \multirow[t]{2}{*}{$\mathrm{t}$} & \multirow[t]{2}{*}{ Sig. } \\
\hline & B & $\begin{array}{l}\text { Std. } \\
\text { Error }\end{array}$ & & & \\
\hline (Constant) & 24.247 & 6.874 & & 3.527 & 0.001 \\
\hline $\begin{array}{l}\text { School } \\
\text { Culture }\end{array}$ & 0.746 & 0.075 & 0.768 & 9.885 & 0.000 \\
\hline
\end{tabular}

Centered on the success test of the school culture component of teachers in SD Negeri in the Keluang District, the $\mathrm{t}$ value is $9,885>$ the $\mathrm{t}$ table price is 1,9944 If the value of $t$ is greater than the table of $t$ and the 0.000 value is less than 0,05 , so Hol accepted there is an important impact on the success of teachers in the school culture SD Negeri in Keluang District.

\section{2) The effect of the Organizational Contribution to Teacher Work}

The organizational commitment relationship model for teacher performance presented in the form of the dependent variable $\mathrm{Y}=49,000+0.379 \mathrm{X}_{2}$. The regression equation significance test can be presented in the table below. 
Table 2. Significance of the Effect of Organizational Commitment on Teacher Performance

\begin{tabular}{|c|c|c|c|c|c|}
\hline \multirow[b]{2}{*}{ Model } & \multicolumn{2}{|c|}{$\begin{array}{r}\text { Unstandardized } \\
\text { Coefficients } \\
\text { Std. }\end{array}$} & $\begin{array}{l}\text { Standardized } \\
\text { Coefficients }\end{array}$ & \multirow[b]{2}{*}{$\mathrm{t}$} & \multirow[b]{2}{*}{ Sig. } \\
\hline & B & $\begin{array}{l}\text { Std. } \\
\text { Error }\end{array}$ & Beta & & \\
\hline $1 \quad$ (Constant) & 49.000 & 5.961 & & 8.220 & 0.000 \\
\hline $\begin{array}{l}\text { Organizational } \\
\text { Commitment }\end{array}$ & 0.379 & 0.052 & 0.661 & 7.257 & 0.000 \\
\hline
\end{tabular}

a. Dependent Variable: Teacher Performance

3) The Impact of School Culture and the

Centered on the test of the importance of the variable organizational commitment to the performance of teachers in SD Negeri in the Keluang District, the $\mathrm{t}$ value is $7.257>$ the $t$ table price is 1.9944 where the $t$ value is greater than the table and the $t$ value is 0.000 which is less than 0.005, so Hol Accepted that there is a major impact on the organizational commitment to the teacher.

\section{Organizational Contribution to Teacher Success}

The model of the relationship between school culture and the organizational commitment to teacher performance presented in the form of the linear regression $\mathrm{Y}=22.368+0.571 \mathrm{X}_{1}+0.157 \mathrm{X}_{2}$, which means that the performance of teachers will increase positively with the school culture and the organizational commitment.

Table 3. Significance of the influence of school culture and organizational commitment on teacher performance

\begin{tabular}{|c|c|c|c|c|c|}
\hline \multirow[b]{2}{*}{ Model } & \multicolumn{2}{|c|}{$\begin{array}{c}\text { Unstandardized } \\
\text { Coefficients }\end{array}$} & \multirow{2}{*}{$\begin{array}{c}\text { Standardized } \\
\text { Coefficients } \\
\text { Beta } \\
\end{array}$} & \multirow[b]{2}{*}{$\mathrm{t}$} & \multirow[b]{2}{*}{ Sig. } \\
\hline & B & $\begin{array}{c}\text { Std. } \\
\text { Error }\end{array}$ & & & \\
\hline $\begin{array}{ll}1 & \text { (Constant) }\end{array}$ & 22.368 & 6.594 & & 3.392 & 0.001 \\
\hline $\begin{array}{l}\text { of school } \\
\text { culture }\end{array}$ & 0.571 & 0.096 & 0.588 & 5.966 & 0.000 \\
\hline $\begin{array}{l}\text { organizational } \\
\text { commitment }\end{array}$ & 0.157 & 0.057 & 0.273 & 2.774 & 0.007 \\
\hline
\end{tabular}

a. Dependent Variable: Teacher Performance

In order to find out the truth of the hypothesis tests, a simultaneous test was carried out using the $\mathrm{F}$ test to determine the impact of school culture variables and organizational commitment on teacher performance. The test criteria shall be as follows: a) if the probability value (significant) is $<0.005$, then $\mathrm{Ho} 3$ is rejected, and b) if the probability value (significant) is $>0.005$, then Ho3 is accepted. The test criteria are as follows for the F test: a) Ha3 is accepted if you have Fcount $>$ Ftable, b) Ho3 is accepted if Fcount $\leqslant$ Ftable is accepted.

Outcomes of the multiple regression analysis can be seen in the table below:

Table 4. The results of multiple regression analysis School culture and organizational commitment to teacher performance

\begin{tabular}{|c|c|c|c|c|c|}
\hline Model & $\begin{array}{l}\text { Sum of } \\
\text { Squares }\end{array}$ & df & $\begin{array}{l}\text { Mean } \\
\text { Square }\end{array}$ & $\mathrm{F}$ & Sig. \\
\hline Regression & 3361.897 & 2 & 1680.948 & 57.521 & $.000^{\mathrm{b}}$ \\
\hline Residual & 1957.946 & 67 & 29.223 & & \\
\hline Total & 5319.843 & 69 & & & \\
\hline
\end{tabular}

a. Dependent Variable: Teacher Performance

b. Predictors: (Constant), School culture, Organizational Commitment

On the basis of the importance test of school culture variables and the organizational commitment to the performance of teachers in SD Negeri in the Keluang district, the $\mathrm{f}$ value is $57.521>$ the $\mathrm{f}$ table price is 3.13 
where the calculated $\mathrm{f}$ value is greater than the $\mathrm{f}$ table and the value is 0.000 which is less than 0.005 , then Ho3 is accepted in such a way that there is a significant influence on the performance of teachers in SD Negeri in the Keluang district between the school culture and the organizational commitment.
To figure out how much effect the regression coefficient has on the dependent variable, you can see it simultaneously in the description model table below.

Table 5. Model Summary of school culture and organizational commitment

\begin{tabular}{lcccc}
\hline Model & R & $\begin{array}{c}\mathrm{R} \\
\text { Square }\end{array}$ & $\begin{array}{c}\text { Adjusted } \\
\mathrm{R} \\
\text { Square }\end{array}$ & $\begin{array}{c}\text { Std. Error } \\
\text { of the } \\
\text { Estimate }\end{array}$ \\
\hline 1 & $.795^{\mathrm{a}}$ & 0.632 & 0.621 & 5.40584 \\
\hline \multicolumn{4}{l}{ a. Predictors: (Constant), school culture, } \\
organizational commitment
\end{tabular}

The table above indicates the value of $\mathrm{R}$ which is a sign of the value of the correlation coefficient. At the value above the correlation value is 0,795 This value can be interpreted as meaning that the relationship between the two study variables is in a strong category. This table also shows the value of the square $\mathrm{R}$ or the coefficient of determination (KD) which shows how much the regression model is formed by the interaction of the independent variables and the dependent variable. The KD value obtained is 0.632 which can be interpreted as an exponential function. $X$ has a contribution effect of $63.2 \%$ on variable $\mathrm{Y}$ and 36.8 , while the other per cent is influenced by factors other than variable $X$.

Essentially, the role of school culture is that of a school identity that has certain characteristics that distinguish it from other schools. This identification may be in the form of curricula, rules, school logos, traditions, uniforms, etc. Culture is not created instantly by schools, but through various processes that are not short-lived. As Komariah stated, at the beginning of its development, school culture was formed on the basis of one's own vision and mission, which was developed as an adaptation to the environment (society) both internally and externally [33].

This study is consistent with the work conducted out through Hayati [34] results showed that (1) the organizational commitment had a positive and significant impact on the performance of Sungai Rotan 1 Senior High School Teachers; (2) the motivation for work has a positive and significant effect on the performance of teachers at Sungai Rotan 1 Senior High School; (3) Combined organizational engagement and enthusiasm for work have a positive and important effect on the success of SMA Sungai Rotan 1 teachers. The conclusion of this study is that there is a need to improve teacher performance, organizational commitment and work motivation. The results of
Darmawan's research (2019) indicate that the influence of school culture on the output of vocational teachers in the tourism family in Tangerang City is important [34].

Organizational commitment is a reflection of where the employee recognizes the organization and is bound by its objectives. Attitudes at work are important because committed people are expected to demonstrate their willingness to work harder to achieve organizational goals. A teacher who has a strong commitment to progress will certainly have a positive impact on his or her work. It is hoped that a strong commitment to school building will improve overall performance.

The expected performance with a high level of organizational commitment is performance on all fronts. Whether it's teacher performance, overall school performance, and an increase in the quality of student learning outcomes. A teacher's work commitment is a link between himself and the duties he considers himself to be a teacher and can give birth to responsibilities that can guide and guide learning activities. A high level of commitment to teaching work is needed in a school organization, because the creation of a high level of commitment will have an impact on the professional work situation.

The success of a teacher in his/her job is largely determined by the level of competence, professionalism and commitment to his/her field of work. The commitment of a person to the organization in which he works demonstrates the power of a person to identify his or her involvement in the organization. This is consistent with Balu et al's view that organizational commitment is an attitude that reflects employees' feelings of likeness or displeasure with respect to the organization [21]. The findings of this study are consistent with Ali's 2019 analysis by others who have suggested that there is a direct positive effect on the organization's dedication to performance [35]. Research 
by Irawati et al. has shown that organizational engagement has a major negative effect on teacher performance [36].

Out of the findings of the normality test, the homogeneity test and the linearity test above, the test analysis results obtained through the SPSS program have fulfilled the requirements to conduct a partial and simultaneous hypothesis analysis between the variables studied using multiple linear regression analysis [37].

\section{CONCLUSION}

Mainly focused on the outcome of the review of data, the effect of certification and work motivation on performance, both partially and simultaneously, can be explained as follows: 1) that school culture has a partial effect on the performance of teachers so that it can be concluded that the first hypothesis is accepted. That Ha1; $\mathrm{X}_{1}$ has a significant effect on $\mathrm{Y}$ because of the $\mathrm{t}$ count $>t$ table $9.885>1.994$. With line equation $\mathrm{Y}=$ $24,247+0.746 \mathrm{X}_{1}$, the magnitude of $\mathrm{X} 1$ 's influence on $\mathrm{Y}$ is $59.6 \%$; 2) in part, this organizational commitment affects the performance of teachers. That Ha1; $\mathrm{X}_{2}$ has a significant effect on $\mathrm{Y}$ because $\mathrm{t}$ counts $>\mathrm{t}$ table $7,257>1,994$. With line equation $\mathrm{Y}=49,000+0.379 \mathrm{X}_{1}$, the magnitude of $\mathrm{X}_{1}$ 's influence on $\mathrm{Y}$ is $43.6 \%$, and 3) that school culture and organizational commitment have a simultaneous (joint) effect on absenteeism in the workplace, so that it can be concluded that the first hypothesis is accepted. The calculated f value of 57.521, the value of $f$ count is greater than the $f$ table or 57.521> 3.13 , the regression equation model: $\mathrm{Y}=22.368+0.571$ $\mathrm{X}_{1}+0.157 \mathrm{X}_{2}$ means that the school culture variables and the organizational commitment have a positive effect on the performance of teachers. The KD value obtained was 0.632 , with a contribution effect of $63.2 \%$ on variable $\mathrm{Y}$.

\section{ACKNOWLEDGMENTS}

Our deepest gratitude goes to Teachers in SD Negeri Keluang District, Chancellor of Palembang PGRI University, Director of the Postgraduate Program of PGRI Palembang University and the Education Management Study Program of PGRI Palembang University, who have supported us in doing this extraordinary thing. This project is funded independently. We also want to thank our Education Management friends who helped us a lot in a short time frame to complete this project.

\section{REFERENCES}

[1] Siagian, S. (2002). Kiat Meningatkan Produktivitas Kerja [Tips for Increasing Work Productivity]. Jakarta.: Rineka Cipta,
[2] Judge \& Robbins S. P. (2008). Perilaku Organisasi [Organizational behavior]. Jakarta.: Salemba empat,

[3] Schein E. H. (2004). The Role of Foundation in Creating Organizational Culture. New York: Mc Graw Hill.

[4] Zamroni. (2011). Pendidikan Demokrasi pada Masyarakat Multikultural [Democracy Education in Multicultural Societies]. Yogyakarta: Gavin Kalam Utama.

[5] Moeljono, D. (2003). Budaya Korporat dan Keunggulan Korporasi [Corporate Culture and Corporate Excellence]. Jakarta.: Media Komputindo.

[6] McShane, M. A., Steven, L. \& Glinow, V. (2008). Organizational Behavior, Fourth. United State America: Mc Graw Hill Company.

[7] Nevizond, C. (2007). Profil Budaya Organisasi (mendiagnosis Budaya dari Merangsang Perubahannya [Organizational Culture Profiling (Diagnosing Culture from Stimulating Its Change]. Bandung: Alfabeta.

[8] Luthans, F. (2009). Perilaku Organisasi, 10th ed [Organizational Behavior, 10th ed]. Yogyakarta: Andi Offset.

[9] Arianto \& Nugroho, D. A. (2013). Pengaruh kedisiplinan, Lingkungan kerja dan budaya kerja terhadap Kinerja tenaga pengajar [The influence of discipline, work environment and work culture on teaching staff performance]. J. Econ., vol. 9, no. 2, pp. 190-200, 2013.

[10] Suriansyah, A. (2014). Hubungan Budaya Sekolah, Komunikasi, Dan Komitmen Kerja Terhadap Kinerja Guru Sekolah Dasar Negeri [Relationship between School Culture, Communication, and Work Commitment on the Performance of Public Elementary School Teachers]. Jurna Cakrawala Pendidikan, vol. 33, no. 3, pp. 356-367, 2014.

[11] Ahmad, D. (2015). Pengaruh Gaya Kepemimpinan Kepala Sekolah dan Budaya Sekolah terhadap Kinerja Guru [The Influence of Principal Leadership Style and School Culture on Teacher Performance]. Jurnal Ilmu Pendidik vol. 21, no. 1, pp. 1-8, 2015.

[12] Setiyati, S. (2014). Pengaruh Kepemimpinan Kepala Sekolah, Motivasi Kerja, Dan Budaya Sekolah Terhadap Kinerja Guru [The Influence of Principal Leadership, Work Motivation, and School Culture on Teacher Performance]. Jurnal Pendidik. Teknol. dan Kejuru, vol. 22, no. 2, pp. 201-207, 2014. 
[13] Fuad, S., \& Srimindarti, C. (2015). Pengaruh Motivasi Dan Komitmen Organisasional Terhadap Kinerja Guru Yang Dimoderasi Oleh Budaya Organisasi Pada Mi Se-Kecamatan Winong Kabupaten Pati (Studi Kasus pada Guru-Guru MI Se-Kecamatan Winong Kabupaten Pati) The Influence of Motivation and Organizational Commitment on Teacher Performance Moderated by Organizational Culture in Noodles in Winong District, Pati Regency (Case Study of MI Teachers in Winong District, Pati Regency). Proceeding SENDI_U. Retrieved from https://www.unisbank.ac.id/ojs/index.php/sendi_u/ article/view/3273.

[14] Aziz, A. (2013). Memahami Organisasi Pendidikan: Budaya dan Reinventing Organisasi Pendidikan [Understanding Educational Organizations: Culture and Reinventing Educational Organizations]. Bandung: Alfabeta.

[15] Purwanto, N. (2014). Evaluasi hasil belajar [Evaluation of learning outcomes]. Yogyakarta: Pusaka Pelajar.

[16] Daryanto. (2015). Pengelolaan Budaya Dan Iklim Sekolah [Management of School Culture and Climate]. Yogyakarta: Gava Media.

[17] Susanto, A. (2014). Teori belajar dan pembelajaran di sekolah dasar [Theory of learning and learning in elementary schools]. Jakarta.: Kencana Prenadamedia Group.

[18] Kreitner, A. R. \& Kinicki. (2011). Perilaku Organisasi [Organizational behavior]. Jakarta.: Salemba empat.

[19] Sopiah. (2008). Perilaku Organisasi [Organizational behavior]. Yogyakarta: Andi Offset.

[20] Judge \& Robbins. (2013). Kinerja Pegawai Teori Pengukuran dan Implikasi [Employee Performance Measurement Theory and Implications] (Terjemahan Pasolong). Jakarta.: Indeks.

[21] Blau, K. G. and Boal. (1989). Using Job Involvement and Organizational Commitment Interactively to Predic Turnover," Jurnal Management vol. 15, no. 2, pp. 115-127.

[22] Prawirosentono. (2009). Manajemen Sumber Daya Manusia Kebijakan Kinerja Karyawan [Human Resource Management Employee Performance Policy]. Yogyakarta: BPFE Yogyakarta.

[23] Mangkunegara, A. P. (2011). Manajemen Sumber Daya Manusia Perusahaan [Company Human Resource Management]. Bandung: Remaja Rosdakarya.
[24] Rivai, V. (2004). Manajemen Sumber Daya Manusia Untuk Perusahaan [Human Resource Management for Companies]. Jakarta.: Raja Grafindo Persada.

[25] Gomes, F. C. (2011). Manajemen Sumber Daya Manusia [Human Resource Management]. Yogyakarta: Andi Offset.

[26] Syukur, F. (2014). Manajemen Sumber Daya Manusia Pendidikan [Human Resource Management Education]. Semarang: PT Pustaka Rizki Putra.

[27] Wahab, A. \& Umiarso. (2011). Kependidikan dan Kecerdasan Spiritual [Education and Spiritual Intelligence. Yogyakarta: Ar-Ruzz.

[28] Fathurrahman, M. (2015). Model Model Pembelajaran [Inovatif Innovative Learning Models]. Jakarta.: Ar-Ruzz.

[29] Musfiqon, H. M. (2012). Metodologi Penelitian Pendidikan [Educational Research Methodology]. Jakarta: PT Prestasi Pustakaraya.

[30] Sugiyono. (2013). Metode Penelitian Kuantitatif dan $R$ dan $D$ [Quantitative Research Methods and $R$ and $D$ ]. Bandung: Alfabeta.

[31] Arikunto. (2010). Prosedur Penelitian Suatu Pendekatan Praktek [Research Procedure A Practice Approach]. Jakarta.: Rineka Cipta.

[32] Sugiyono. (2012). Metode Penelitian Pendidikan: Pendekatan Kuantitatif, Kualitatif, dan $R \& D$ [Educational Research Methods: Quantitative Approaches, Qualitative, $R$ and D]. Bandung: Alfabeta.

[33] Komariah, T., Aan \& Cepi. (2010). Visionary Leadership Menuju Sekolah Efektif [Visionary Leadership Towards Effective Schools]. Jakarta.: Bumi Aksara.

[34] Hayati, R., \& Arafat, Y., \& Artanti, P. S. (2020). Pengaruh Komitmen Organisasi Dan Motivasi Kerja Terhadap Kinerja Guru [The Effect of Organizational Commitment and Work Motivation on Teacher Performance]. Jurnal Manajemen, Kepemimpinan, dan Supervisi Pendidik., vol. 5, no. 2.

[35] Ali, K. M. (2019). Pengaruh Etika Kerja Islam dan Komitmen Organisasi terhadap Kinerja Guru [The Influence of Islamic Work Ethics and Organizational Commitment on Teacher Performance]. Jurnal Akuntabilitas Manajemen Pendidik vol. 7, no. 2.

[36] Sudarno, I \& Komardi, D. (2019). Effect of Work Motivation, Organizational Culture on Work 
Satisfaction and Performance of Teachers in Public Junior High School Pekanbaru. Jurnal Ilmu Manajemen vol. 7, no. 2, pp. 210-221.

[37] Bimayu, W., Kristiawan, M., \& Fitriani, Y. (2020). The Effect of Emotional Intelligence, Student's Motivation toward Student's Achievement. International Journal of Progressive Sciences and Technologies (IJPSAT), 20(1), 06-16. 